\title{
Features of the Role Structure and Relationships in Korean and Russian Couples
}

\author{
Vlada Pishchik*a, Irina Lia
}

[a] Faculty of Psychology, Pedagogy and Defectology, Don State Technical University, Rostov-on-Don, Russia.

\begin{abstract}
The modern world leads to collapse of the marriage institution. It causes a lot of problems. One of them raises the question of how ethnic culture preserves the relationships in married couples within traditional framework if these couples live in a different national cultural; environment. Both Russian and Korean are collectivism cultures. However, in Russia individualism is spreading very quickly among young people. In Korean families elderly people have a big influence, they adhere to Confucianism. Russians have more democratic relations and adhere to Christianity. We tried to prove that Korean couples still have traditional marital roles, relationships, and attitudes. The purpose of the study is to compare the role structure, features of the husband-wife relationship, and attitudes in the Russian and Korean married couples living in Russia. Russian and Korean family roles are considered in the article, as well as the features of family attitudes that characterize the type of family and describe the mentality of Russians and Koreans. A comparative cross-methodology was applied within pairs and between Korean and Russian pairs, and data was factorized. The sample consisted of $n=80$ participants. We used the following methods: measurement of roles in a family; study of understanding relationships, emotional attraction and authoritarianism; attitudes towards love, children, money, and divorce. The scientific novelty of the research is expressed in the fact that the comparison with various aspects of the structure of roles and relationships in modern Korean and Russian couples is carried out, the members of married couples of both nationalities are compared. The study showed that Russians and Koreans living in Russia have become very similar in their lifestyle, but they differ in the internal arrangement of the family, role preferences and attitudes in a married couple, especially in relation to children, sex, psychological climate and financial responsibility. The data obtained can be used in family counseling and therapy.
\end{abstract}

Keywords: married couples, the Russians, the Koreans, family roles, family attitudes, ethnic characteristics, sexual relations

Interpersona, 2020, Vol. 14(2), 137-149, https://doi.org/10.5964/ijpr.v14i2.3793

Received: 2020-05-31. Accepted: 2020-10-23. Published (VoR): 2020-12-22.

*Corresponding author at: Don State Technical University, Ploshchad' Gagarina, 1, 344002 Rostov-on-Don, Rostov Oblast, Russia. E-mail: vladaph@yandex.ru

This is an open access article distributed under the terms of the Creative Commons Attribution 4.0 International License, CC BY 4.0 (https://creativecommons.org/licenses/by/4.0/), which permits unrestricted use, distribution, and reproduction in any medium, provided the original work is properly cited.

Research in the field of family relations of various ethnic groups shows that family relations have changed over the course of several decades in different countries. The trends of change in married couples described in the works of Pinsof, Lebow (Pinsof \& Lebow, 2005) were confirmed. The changes are expressed in the structure (Ivanova \& Ustinova, 2016; Jansen, Harris, \& Rossi, 2020; Kabakova \& Maulsharif, 2013; Lieber, Clarke, Timæus, Carson Mallinson, \& Kinra, 2020) and dynamics (Schenk \& Dykstra, 2012) of the family, role preferences (Garcia, Bucher-Maluschke, Pérez-Angaritaa, Vargas-Veleza, \& Pereiraa, 2016; Spivatchuk, 2017), attitudes to various institutions of society, and changes in values (Delelis \& Heuschena, 2019; Masuda, Sortheix, Beham, \& Naidoo, 2019). There is still an increase in the number of unmarried women and, in particular, unmarried men, which affects the level of depression. In the social environment, not only intimate sexual relations outside of marriage are multiplying, but also the number of single-parent families is growing, 
and the generic essence is being lost. The Roman club calls for a balance in the relationship between men and women (von Weizsäcker \& Wijkman, 2018), but it is very difficult to achieve. At the same time, according to surveys of young people in Russia, the value of the family is in the top positions among other values (Maslennikova \& Nepryahina, 2019). The family is a significant value, but the content of the implementation of marriage relationships is undergoing changes.

Khammatova (2012) studied the social and psychological characteristics of the Russian, Tatar and Bashkir families living in Russia. Khammatova (2012) showed that families of different ethnic groups differ in their psychological component (parental and household sphere), which determines the choice of parenting style and the formation of a psychological climate in each ethnic group. Vlasova (2020) has devoted her time to an empirical study of the ethnic characteristics of conflicts in spouses belonging to different ethnic groups on the example of the Russians, Armenians, and Tatars and mixed couples. She found out that Russian couples are the most conflicted.

As the researchers show, married couples of the collectivist culture are more likely to accept conceptually-oriented communication, whereas married couples of collectivist cultures tend to use socially-oriented communication (Singh \& Nayak, 2016).

According to many researchers in the field of family relations, one of the main problems of the role structure of the family is inter-ethnic differences among all peoples in the world. Culture and mentality are reflected in the internal style of life of the family.

The problem of the relationship between the ethnic group and the family structure is relevant due to the presence of many different nationalities in Russia, whose ethnopsychological features have not yet been sufficiently studied. In Russian studies, Korean couples are rarely researched.

Russia is a multinational state. Here married couples are subject to serious changes due to modern trends in the destruction of the family institution.

Today when the world has changed greatly we would like to understand what will hold back traditional forms of relationships in married couples, and whether globalism has affected them so much (Chang \& Kim, 2018; Han et al., 2019; Jaehn, Bobrova, Saburova, \& Cook, 2020; Lee, Park, Ju, \& Kim, 2018). There is an assumption that ethnic culture keeps relations in married couples within the traditional framework, if they live in a different national cultural environment. As part of our research, we studied Russian and Korean couples living in the South of Russia. Russian and Korean cultures belong to collectivism (Triandis, 2004). But in Russia, individualism is spreading very actively among young people. As Oyserman (2011) noted, the situation can change the collectivistic orientation. However, in Korean families, older people have more influence, relationships are arranged hierarchically, and they adhere to Confucianism. Russians have more democratic relations, sometimes they show disdain for their elders and adhere to Christianity.

The family is an indicator of the well-being of society, stabilization and elimination of tension. This is why it is so important to study relationships in married couples.

Our research was conducted with the aim to compare the role structure, features of the husband-wife relationship, and attitudes in the Russian and Korean married couples living in Russia. We assumed that Korean 
couples, despite the fact that they all live in the same Russian space, will show more collectivistic, traditional role distributions, relationships and attitudes.

Based on the presented problem, we put forward several research hypotheses:

$\mathrm{H} 1$. The role structure in Korean couples is more traditional and collectivistic than in Russian couples.

H2. Interpersonal relationships between husband and wife in Korean couples are more traditional, collectivistic compared to Russian couples.

H3. Korean couples have more traditional and collectivistic attitudes than Russian couples.

\section{Method}

\section{Participants}

Initially, we involved 30 Russian and 28 Korean married couples in the study. But in the course of the study, some of the pairs were eliminated.

The empirical object was 20 Russian and 20 Korean married couples (officially registered, traditional, heterosexual) aged between 22 and 38 years $(M=30, S D=13.4)$, a husband and a wife who work, have 1-2 children, Russian couples adhere to the Orthodox religion, Korean couples adhere to Confucianism, and all married couples live in Rostov-on-Don, the southern region of Russia. All couples live separately from their parents and speak Russian. There were no nationally mixed pairs. In Russian and Korean couples, husbands and wives are married from 2 to 19 years.

\section{Instruments}

The following psychodiagnostic methods were used to prove the proposed hypotheses and solve the set tasks:

The method of "Roles distribution in the family" (created by Aleshina, Gozman, \& Dubovskaya, published in Andreeva, 2005); Questionnaire "Understanding, emotional attraction, authority" (UEA; created by Volkova, modification of the questionnaire Slepkova, published in Oliferovich, Zinkevich-Kuzemkina, \& Velenta, 2006); Questionnaire "Measuring attitudes in a married couple" (created by Aleshina \& Gozman, published in Shapar, 2006).

The method of "Distribution of roles in the family" identifies the following roles: 1) Parenting-questions; 2) The emotional climate in the family (the role of the family "psychotherapist"); 3) Material support for the family; 4) Organization of entertainment; 5) The role of "host," "hostess"; 6) Sexual partner; 7) Organization of family subculture. The indexes for each area are calculated as the arithmetic average of the three questions. The higher the score, the more this role in the surveyed family is realized by the wife, the lower-the more realized by the husband. If the value is close to the average value, then this role is implemented by both spouses approximately equally. Since both spouses participate in the survey, it is possible not only to find out the opinion of each of them about the distribution of roles in the family, but also to compare their responses to the proposed questions. Misalignment of the positions of the spouses in assessing the distribution of roles in the family can be an indicator of conflict points (explicit or hidden) in the relationship between them. 
The "Understanding, emotional attraction, authority" questionnaire was designed to measure the degree of understanding, emotional attractiveness, and respect for partners in a marriage. The questionnaire consists of 45 statements that relate to the relationship between partners in marriage. The text of the questionnaire contains three scales reflected in the name of the method: understanding, emotional attraction, and authority (respect). Each scale includes 15 questions-statements. Understanding (1-15 statements) is the presence of a picture of the partner's personality in the subject, a subjective sense of knowledge of his personal characteristics. The subject who notes a high understanding is not difficult to interpret the behavior, thoughts, feelings and intentions of the partner, and can easily take them into account when communicating with the partner. Misunderstanding - lack of a clear picture of the partner's personality, difficulties in interpreting and explaining his thoughts, feelings, and actions. Emotional attraction is the attractiveness of the partner, the desire to communicate with him, to deal with him, the therapeutic effect of contact on the subject. Low ratings on this scale characterize difficulties in communication between partners, a feeling of fatigue from each other. Authority (respect) is an indicator of how much the partner is accepted as a person, how much the subject shares his worldview, interests, opinions and accepts them as a standard. Disrespect-contempt for the partner as a person. The sum of points within a single scale is a numerical measure of the measured parameter. Thus, the method allows us to define the measure of understanding, attractiveness and respect on a scale of 0-30 points, where 0 is the minimum and 30 are the maximum points on the scale.

The questionnaire "Measuring attitudes in a married couple" is designed to study the attitudes of spouses on the most important areas of human life in family interaction, to determine the degree of socio-psychological compatibility of partners in marriage. When creating the questionnaire, the authors were guided by ideas about which attitudes of a person can have the most powerful influence on their intra-family relations. The questionnaire consists of 40 judgments that express a particular position on 10 different areas that are important to people: 1) attitude to people; 2) alternative between a sense of duty and pleasure; 3) attitude to children; 4) attitude to the autonomy or dependence of the spouses; 5) attitude to divorce; 6) attitude to romantic love; 7) assessment of the importance of the sexual sphere in family life; 8) attitude to the "taboo of sex"; 9) attitude to the patriarchal or egalitarian structure of the family; 10) attitude to money. For each scale, the arithmetic mean of the four responses is calculated; the alternatives are assigned the following values: 4 (yes, it is), 3 (probably it is), 2 (unlikely it is), 1 (no, it is not).

The following methods of statistical analysis were also used for calculating and comparing data: the Kruskal-Wallis criterion, the Jonkheer-Terpster criterion of ordered alternatives, and factor analysis.

\section{Procedure}

The first stage involved the search and selection of volunteers for the study. Subjects suitable for this research are those people who are married. Both spouses must belong to either Korean or Russian nationality. International families are not subject to research. The social network Vkontakte was used to search for potential test subjects, since there are many communities in It, including those that are nationally oriented. In it, I published an entry with brief information about me, about the upcoming research, and requirements for those who wish to participate. It was from the Vkontakte community that the majority of people from the sample of Korean subjects responded. In addition to social networks, I used the opportunity to contact the family center, where there were those who wanted to participate in the study. All the people found were in the age category from 22 to 45 , the total number is 80 people. 
The subjects were asked to fill out forms of techniques. The subjects were interested in testing because they were promised feedback in the form of a detailed interpretation of their results. Due to the tight work schedule of the subjects, a week ( 7 days) was given for completing the questionnaires.

The second stage is the processing of all the obtained material that was obtained during the research. The methods were processed by calculating points and comparing them with the key. After that, all the data was entered in the Excel table, to clarify the results, as well as for further analysis.

The third stage consisted of drawing up graphs to show the results. After compiling the Excel table, data was processed using the statistical program SPSS (Version 22) for Windows. And it was used to identify which scales and groups differ and what these differences are, as well as to factorize the data. Based on this, the relevant conclusions were drawn.

\section{Results}

First, we determined the structure of role-playing in pairs. The following roles were defined: parenting, emotional climate, material support, organization of entertainment, the role of host/hostess, sexual partner, organization of family subculture. The results are shown in Table 1 and Table 2.

Table 1

Descriptive Statistics of Family Role Selections for Korean Couples

\begin{tabular}{|c|c|c|c|c|c|c|c|c|}
\hline \multirow[b]{2}{*}{ Role } & \multicolumn{2}{|c|}{ Minimum } & \multicolumn{2}{|c|}{ Maximum } & \multicolumn{2}{|c|}{$M$} & \multicolumn{2}{|c|}{$S D$} \\
\hline & $\mathbf{H}$ & $\mathbf{W}$ & $\mathbf{H}$ & $\mathbf{W}$ & $\mathbf{H}$ & $\mathbf{W}$ & H & $\mathbf{W}$ \\
\hline Parenting-questions & 2.00 & 2.60 & 4.00 & 4.00 & 2.9600 & 3.2500 & 0.57711 & 0.43589 \\
\hline $\begin{array}{l}\text { The emotional climate in the family (the } \\
\text { role of the family "psychotherapist") }\end{array}$ & 2.00 & 2.30 & 4.00 & 3.60 & 3.2200 & 3.0400 & 0.67090 & 0.38987 \\
\hline Material support for the family & 2.00 & 2.00 & 4.00 & 4.00 & 2.8800 & 2.7400 & 0.61009 & 0.63279 \\
\hline Organization of family subculture & 1.00 & 1.00 & 3.00 & 3.30 & 1.3600 & 1.5700 & 0.63941 & 0.65863 \\
\hline Sexual partner & 2.00 & 2.30 & 3.30 & 3.30 & 2.7100 & 2.6300 & 0.42661 & 0.34959 \\
\hline The role of "host", "hostess" & 2.00 & 2.00 & 3.60 & 3.30 & 2.7100 & 2.6300 & 0.53793 & 0.40013 \\
\hline Organization of entertainment & 1.00 & 1.60 & 3.60 & 3.30 & 2.2100 & 2.3700 & 0.70554 & 0.50063 \\
\hline
\end{tabular}

Note. Valid $N$ (listwise) $=20 / 20 . \mathrm{H}=$ husband; $\mathrm{W}=$ wife.

Table 2

Descriptive Statistics of Family Role Selections for Russian Couples

\begin{tabular}{|c|c|c|c|c|c|c|c|c|}
\hline \multirow[b]{2}{*}{ Role } & \multicolumn{2}{|c|}{ Minimum } & \multicolumn{2}{|c|}{ Maximum } & \multicolumn{2}{|c|}{$M$} & \multicolumn{2}{|c|}{$S D$} \\
\hline & $\mathbf{H}$ & $\mathbf{w}$ & $\mathbf{H}$ & $\mathbf{w}$ & $\mathbf{H}$ & $\mathbf{w}$ & $\mathbf{H}$ & $\mathbf{w}$ \\
\hline Parenting-questions & 2.30 & 2.30 & 3.00 & 3.30 & 2.8100 & 2.8500 & 0.25319 & 0.32525 \\
\hline $\begin{array}{l}\text { The emotional climate in the family (the } \\
\text { role of the family "psychotherapist") }\end{array}$ & 2.00 & 2.30 & 3.30 & 3.60 & 2.8300 & 2.8500 & 0.43541 & 0.46169 \\
\hline Material support for the family & 1.30 & 2.00 & 3.00 & 3.30 & 2.0700 & 2.5800 & 0.53518 & 0.53666 \\
\hline Organization of family subculture & 2.30 & 1.00 & 4.00 & 2.60 & 2.8100 & 1.8400 & 0.50565 & 0.40833 \\
\hline Sexual partner & 2.00 & 1.30 & 3.30 & 3.30 & 2.7200 & 2.3400 & 0.43237 & 0.53744 \\
\hline The role of "host", "hostess" & 1.60 & 1.60 & 3.30 & 3.30 & 2.4000 & 2.3400 & 0.50471 & 0.51340 \\
\hline
\end{tabular}




\begin{tabular}{|c|c|c|c|c|c|c|c|c|}
\hline \multirow[b]{2}{*}{ Role } & \multicolumn{2}{|c|}{ Minimum } & \multicolumn{2}{|c|}{ Maximum } & \multicolumn{2}{|c|}{$M$} & \multicolumn{2}{|c|}{$S D$} \\
\hline & $\mathbf{H}$ & $\mathbf{w}$ & $\mathbf{H}$ & $\mathbf{w}$ & $\mathbf{H}$ & $\mathbf{w}$ & $\mathbf{H}$ & $\mathbf{w}$ \\
\hline Organization of entertainment & 2.30 & 1.60 & 3.30 & 3.60 & 2.6300 & 2.5300 & 0.40795 & 0.60706 \\
\hline
\end{tabular}

Note. Valid $N$ (listwise) $=20 / 20 . \mathrm{H}=$ husband; $\mathrm{W}=$ wife.

There were no differences in the roles between the groups of husbands and wives in the Russian and Korean samples. However, differences were found between the groups of the two nationalities. There were differences between groups of husbands on the roles of organization of family subculture $(U=68.0$, Asymptotic $p=.16)$, on the roles of parenting $(U=54.2$, Asymptotic $p=.34)$, material security $(U=15.52$, Asymptotic $p$ $=.08)$, emotional climate $(U=55.1$, Asymptotic $p=.20)$. Russian husbands choose the material security role compared to Korean husbands based on the interpretation of the results of the method, but this means that Russian wives are more focused on this role. In Korean couples, husbands are more focused on the role of material security. The role of raising children in Russians is more chosen by their wives, and in Korean couples by their husbands.

Korean wives rated the roles of parenting and emotional climate higher than Russian wives $(U=82.1$, Asymptotic $p=.61$ ). The hypothesis of the $\mathrm{H} 1$ group was partially confirmed. Next, we wanted to see what relationships make the base of marriages. The results on the characteristics of relationships in pairs are shown in Table 3 and Table 4.

Table 3

Descriptive Statistics of Relationship Indicators for Russian Couples

\begin{tabular}{|c|c|c|c|c|c|c|c|c|}
\hline \multirow[b]{2}{*}{ Relationship } & \multicolumn{2}{|c|}{ Minimum } & \multicolumn{2}{|c|}{ Maximum } & \multicolumn{2}{|c|}{$M$} & \multicolumn{2}{|c|}{$S D$} \\
\hline & $\mathbf{H}$ & $\mathbf{w}$ & $\mathbf{H}$ & $\mathbf{w}$ & $\mathbf{H}$ & $\mathbf{w}$ & $\mathbf{H}$ & $\mathbf{w}$ \\
\hline Understanding & 7.00 & 20.00 & 30.00 & 30.00 & 24.5000 & 25.3000 & 6.42774 & 3.37327 \\
\hline Emotional attraction & 15.00 & 17.00 & 30.00 & 30.00 & 25.0000 & 24.9000 & 4.85582 & 4.75616 \\
\hline Authority & 17.00 & 17.00 & 26.00 & 26.00 & 22.0000 & 21.5000 & 2.97357 & 2.94690 \\
\hline
\end{tabular}

Note. Valid $N$ (listwise) $=20 / 20 . \mathrm{H}=$ husband; $\mathrm{W}=$ wife.

Table 4

Descriptive Statistics of Relationship Indicators for Korean Couples

\begin{tabular}{|c|c|c|c|c|c|c|c|c|}
\hline \multirow[b]{2}{*}{ Relationship } & \multicolumn{2}{|c|}{ Minimum } & \multicolumn{2}{|c|}{ Maximum } & \multicolumn{2}{|c|}{$M$} & \multicolumn{2}{|c|}{$S D$} \\
\hline & $\mathbf{H}$ & $\mathbf{W}$ & $\mathbf{H}$ & $\mathbf{w}$ & $\mathbf{H}$ & $\mathbf{w}$ & $\mathbf{H}$ & $\mathbf{w}$ \\
\hline Understanding & 16.00 & 20.00 & 30.00 & 27.00 & 24.0000 & 23.3000 & 4.07818 & 2.79285 \\
\hline Emotional attraction & 14.00 & 15.00 & 30.00 & 30.00 & 25.3000 & 26.0000 & 5.08972 & 4.83409 \\
\hline Authority & 20.00 & 14.00 & 30.00 & 28.00 & 23.0000 & 22.5000 & 3.40279 & 5.27656 \\
\hline
\end{tabular}

Note. Valid $N$ (listwise) $=20 / 20 . \mathrm{H}=$ husband; $\mathrm{W}=$ wife.

Differences in the relationships of intra-family couples were not found. Differences between the Korean and Russian husbands were not found on these scales. There were no differences between the wives of the Russian and Korean couples. 
The results of the questionnaire "Measuring the levels of understanding, emotional attraction and authority" are shown in Table 3 and Table 4. All the surveyed couples demonstrated a sufficiently high level of understanding, emotional attraction and respect, which makes it possible to characterize the relationship of the spouses as prosperous.

As we can see, in Russian couples, the understanding, emotional attractiveness and respect of the husband and wife are at a high level, on equal approach. In Korean couples, there is the same trend, but husband's authority is higher. This confirms the hypothesis of tradition character in the relations of Korean couples. The $\mathrm{H} 2$ hypothesis was partially confirmed.

Table 5 and Table 6 shows the distribution by attitudes. In the Russian couple, a significant difference was found on the scale "Evaluating the value of the sexual sphere" $(U=18$, Asymptotic $p=.015)$ and "Attitude to the autonomy or dependence of the spouses" $(U=14$, Asymptotic $p=.010)$. There is a predominance in men. In Korean couples, there are differences between husband and wife in the attitude "Sense of duty/pleasure" $(U$ $=85.5$, Asymptotic $p=.009)$, "Attitude to the autonomy or dependence of the spouses" $(U=15.5$, Asymptotic $p=.013)$ and "Attitude to divorce" $(U=20.5$, Asymptotic $p=.023)$. In Russian couple men strive for autonomy and in Korean women strive for autonomy.

Table 5

Descriptive Statistics of Family Related Attitudes for Russian Couples

\begin{tabular}{|c|c|c|c|c|c|c|c|c|}
\hline \multirow[b]{2}{*}{ Attitude } & \multicolumn{2}{|c|}{ Minimum } & \multicolumn{2}{|c|}{ Maximum } & \multicolumn{2}{|c|}{$M$} & \multicolumn{2}{|c|}{$S D$} \\
\hline & H & $\mathbf{W}$ & $\mathbf{H}$ & $\mathbf{W}$ & $\mathbf{H}$ & $\mathbf{W}$ & $\mathbf{H}$ & $\mathbf{W}$ \\
\hline Attitude to people & 7.00 & 5.00 & 10.00 & 11.00 & 8.3000 & 7.6000 & 1.45458 & 2.01050 \\
\hline Sense of duty/pleasure & 10.00 & 6.00 & 12.00 & 12.00 & 11.2000 & 10.3000 & 0.76777 & 1.65752 \\
\hline Attitude to children & 5.00 & 5.00 & 10.00 & 11.00 & 7.4000 & 8.4000 & 1.90291 & 2.43656 \\
\hline Orientation to jointlseparate activities & 5.00 & 8.00 & 13.00 & 13.00 & 10.4000 & 10.7000 & 2.30332 & 1.71985 \\
\hline Attitude to divorce & 5.00 & 5.00 & 11.00 & 13.00 & 8.6000 & 8.8000 & 1.90291 & 2.41922 \\
\hline Evaluating the value of the sexual sphere & 10.00 & 5.00 & 13.00 & 12.00 & 11.2000 & 9.1000 & 1.00525 & 2.02355 \\
\hline Attitude to money & 10.00 & 9.00 & 14.00 & 14.00 & 11.2000 & 10.7000 & 1.10501 & 1.38031 \\
\hline
\end{tabular}

Note. Valid $N$ (listwise) $=20 / 20 . \mathrm{H}=$ husband; $\mathrm{W}=$ wife.

Table 6

Descriptive Statistics of Family Related Attitudes for Korean Couples

\begin{tabular}{|c|c|c|c|c|c|c|c|c|}
\hline \multirow[b]{2}{*}{ Attitude } & \multicolumn{2}{|c|}{ Minimum } & \multicolumn{2}{|c|}{ Maximum } & \multicolumn{2}{|c|}{$M$} & \multicolumn{2}{|c|}{$S D$} \\
\hline & $\mathbf{H}$ & $\mathbf{w}$ & $\mathbf{H}$ & $\mathbf{w}$ & $\mathbf{H}$ & $\mathbf{w}$ & $\mathbf{H}$ & $\mathbf{w}$ \\
\hline Attitude to people & 8.00 & 7.00 & 11.00 & 10.00 & 9.0000 & 8.8000 & 1.02598 & 1.28145 \\
\hline Sense of duty/pleasure & 7.00 & 9.00 & 11.00 & 12.00 & 9.6000 & 11.2000 & 1.14248 & 1.10501 \\
\hline Attitude to children & 4.00 & 6.00 & 13.00 & 13.00 & 9.4000 & 10.8000 & 2.68328 & 2.19089 \\
\hline Orientation to jointlseparate activities & 6.00 & 9.00 & 13.00 & 13.00 & 11.2000 & 11.2000 & 2.14231 & 1.70448 \\
\hline Attitude to divorce & 7.00 & 6.00 & 13.00 & 10.00 & 8.5000 & 7.1000 & 1.90567 & 1.55259 \\
\hline Evaluating the value of the sexual sphere & 9.00 & 9.00 & 14.00 & 14.00 & 11.2000 & 11.3000 & 1.93581 & 1.71985 \\
\hline Attitude to money & 10.00 & 10.00 & 15.00 & 15.00 & 11.6000 & 11.8000 & 1.46539 & 1.50787 \\
\hline
\end{tabular}

Note. Valid $N$ (listwise) $=20 / 20 . \mathrm{H}=$ husband; $\mathrm{W}=$ wife. 
Comparing the men of the Korean and Russian groups, it was found out that there are differences in the scale "Evaluating the value of the sexual sphere" $(U=85$, Asymptotic $p=.007)$, "Sense of duty/pleasure" $(U=12$, Asymptotic $p=.003$ ).

The wives of Korean and Russian groups showed that there are differences on the scale "Evaluating the value of the sexual sphere" $(U=76.5$, Asymptotic $p=.043)$. The H3 hypothesis was partially confirmed.

To identify the relationship factors in couples, we factorized the data (using the principal component method).

In the group of the Russian couples 8 components had $84.52 \%$ dispersion:

Component 1 we called "Family relations," based on the scales included in it. It is represented by the following scales: "Organization of family subculture" (weight $=0.83$ ), "Organization of entertainment" (0.83), "Material support"(0.81), "Parenting" (-0.58), "Attitude to children" (0.54).

Component 2 "Role structure of a couple"- "The role of host/hostess" (0.74), "Emotional attraction in pair" (-0.68), "Sense of duty/pleasure" (-0.68), "Attitude to divorce" $(0.58)$, "Attitude to the prohibition of sex" (0.52).

Component 3 "Educational position"-_Parenting" (0.64), "Patriarchal/egalitarian structure of the family" $(-0.57)$.

Component 4 "Emotional relations"- "Understanding in pair" (-0.6), "Emotional attraction in pair" (0.56), "Attitude to divorce" (0.56).

Component 5 "Socio-psychological climate in a couple"- "Emotional climate" (-0.61), "Attitude to people" (0.51).

Component 6 "Sex in a couple"-“Attitude to the prohibition of sex" (0.67).

Component 7-“Emotional climate” (-0.5).

There were no significant variables in Component 8.

In the group of Korean couples, six components were identified that make up $79.22 \%$ of the dispersion:

Component 1 "Family sphere"- “Organization of family" (-0.82), "The role of the host/hostess" $(0.78)$, "Authority in pair" (-0.75), "Emotional attraction in pair" (-0.73), "Emotional climate" (0.73), "Patriarchal/egalitarian" (-0.69), "Attitude to love of the romantic type" (0.66), "Material support" (-0.66), "Attitude to children" (0.57).

Component 2 "Sexual relations"- "Sexual partner" (-0.67), "Attitude to money" (0.64), "Organization of entertainment" (0.61), "Parenting" (-0.57), "Sense of duty/pleasure" (-0.52).

Component 3 "Family budget"- “Understanding in pair" (-0.72), "Attitude to money" (0.54).

Component 4 "Responsibility in a couple"- "Attitude to the prohibition of sex" (0.6), "Material support" (0.54), "Attitude to divorce" (-0.52), "Parenting" (0.5).

Component 5 "Attitude to people"- "Attitude to people" (0.55), "Attitude to love of the romantic type" $(-0.52)$, "Emotional attraction in pair" (-0.51).

Component 6-“Sexual sphere" (0.69). 


\section{Discussion}

Our study showed that there were no differences in role preferences between the groups of husbands and wives in the Russian and Korean samples. This may mean that both in Russian and Korean couples, there is a clear functional distribution of roles between husband and wife, and there is no mixing of roles, role conflict. However, in the diagram (Table 1 and Table 2), we see some discrepancies in the group of Russian couples on the role of the emotional climate and material support of the family. We assume that these are the most problematic areas in family relationships. This is confirmed in other studies of the authors (Romanova \& Tsinchenko, 2019; Spivatchuk, 2017; Vlasova, 2020).

Korean subjects scored more points when evaluating the roles of parenting and emotional climate, which means that they prefer to assign these roles to a woman, and the role of responsibility for financial support to a man. That is, the higher the score, the more this or that role is assigned to a woman. The lower the score, the more this role is assigned to a man. We can assume that the way of Korean married couples is traditional, patriarchal, which confirmed the hypothesis H1. This is confirmed in the study of Ushakov (Ushakova \& Hugh, 2007). The responses of the Russian subjects indicate an even distribution of roles between the spouses. This may indicate that Russian couples are predominantly egalitarian. This is confirmed by the research (Ivanova \& Ustinova, 2016; Spivatchuk, 2017).

There were also some specific features in relationships in couples. In Korean couples, the husband has more authority. Understanding and emotional appeal were revealed in all couples. The similar result can be found in the work (Delelis \& Heuschena, 2019; Han et al., 2019). In Russian couples, the role of maintaining the emotional climate is played by the husband, and in Korean couples, this role is played by the wife. The hypothesis $\mathrm{H} 2$ was confirmed again.

The results of the family attitudes survey show differences between groups in the following attitudes: attitudes towards children, attitudes towards divorce, and attitudes towards the taboo of sex. The Russian subjects rated these attitudes significantly lower. This means that the Russians are ready to build families that will lack an educational function, in other words, they often choose to live without children. Furthermore, Russian families are more loyal to divorce, not regarding it as a threat to marriage, and the topic of sexual relations is not forbidden for them. In other words, the higher the score, the more clearly the attitude to any setting is shown. This is confirmed in a number of studies (Andreeva, 2005 ; Romanova \& Tsinchnko, 2019).

The responses of the Korean couples indicate opposite views on the specified attitudes. This is confirmed by research (Lee \& Kim, 2018; Lee, Tsoi, Tsoi, Chen, \& Yugai, 2003; Yang, Khoo-Lattimore, \& Yang, 2020). As we can see, there are significant differences in attitudes to children, attitudes to divorce, and attitudes to the prohibition of sex. Korean families adhere to more conservative attitudes that set strict limits and prohibit families from divorcing, openly discussing sexual relationships, and prioritize families with children. Perhaps that's why Korean women are more focused on autonomy than Russian women. This corresponds to the general global trends (Gressel, Rashed, Maciuika, \& Bhavani, 2020) Psychological characteristics of Russians are characterized by openness and flexibility in making decisions, forming new relationships, and so on.

Factor analysis allowed us to construct a hypothetical relationship construct in the Russian couples, including family relationships, roles, educational positions and emotional relationships. In Korean couples, the relation- 
ship construct includes: family spheres, sexual relations, family budget, responsibility in a couple, attitude to people. If to expand the sample and add mixed couples it could increase the evidence for some hypotheses.

\section{Conclusion}

According to the conducted research we came to the following conclusions: the Russians and Koreans living in Russia do not differ much from each other due to the adaptation of Korean immigrants to the Russian culture and mentality. However, the Korean mentality does not disappear and manifests itself in family relationships. Compared to Russians, Koreans are more conservative people. Family and maintaining strong family ties are very important for Koreans. The birth of children for Koreans is the main goal of a married couple.

In matters relating to parenting and financial support the Russians and the Koreans act differently. Russian spouses share their responsibilities more or less equally. They try to raise a child equally, earn money and provide for their family. In the Korean family, the picture is different. Here the household chores and upbringing of the child is mainly on the shoulders of women, men in turn take on the role of a breadwinner who provides his family with material goods. These were differences related to the distribution of life.

The last group of differences is related to the attitudes and beliefs of the individual. There are two areas that people of different nationalities think differently about. This is the attitude to children and the assessment of the prohibition of sex.

Russians, on the other hand, have more freedom of choice in their life and family life. Children and their families stop being of special value for some Russian people. The Russian people are much more individualistic than the Korean people. Among other things, Russians are more relaxed, determined and open. These features extend to the sexual sphere of life. It is easier for Russians to open up to others and freely discuss even the most sensitive issues. Most Koreans consider it unacceptable to openly and directly talk about it. For Koreans, unlike Russians, the degree of modesty and restraint of a person is very important.

The study has practical significance, which is expressed in the applicability of knowledge in the field of interethnic psychological characteristics in counseling, family and couple therapy, opens the possibility of a more objective interpretation of people's behavior, as the spectrum of their ethnicity is added.

\section{Funding}

The authors have no funding to report.

\section{Competing Interests}

The authors have declared that no competing interests exist.

\section{Acknowledgments}

The authors have no support to report. 


\section{References}

Andreeva, T. V. (2005). Psikhologiya sovremennoi sem'i [Psychology of the modern family] (pp. 427-431). Saint Petersburg, Russia: Publishing House of the Speech.

Chang, I., \& Kim, B. H. S. (2018). Influencing factors to have an additional child by working women in Korea. The Social Science Journal, 55, 116-127. https://doi.org/10.1016/j.soscij.2017.11.001

Delelis, G., \& Heuschena, M. (2019). Dyadic adjustment in couples: How partners' social value within couple and emotional competences predict it. Interpersona, 13(1), 96-113. https://doi.org/10.5964/ijpr.v13i1.340

Garcia, A., Bucher-Maluschke, J. S. N. F., Pérez-Angaritaa, D. M., Vargas-Veleza, Y. E., \& Pereiraa, F. N. (2016). Couple and family relationships in Latin American social comparative studies. Interpersona, 10(2), 109-124. https://doi.org/10.5964/ijpr.v10i2.259

Gressel, C. M., Rashed, T., Maciuika, L. A., \& Bhavani, R. R. (2020). Vulnerability mapping: A conceptual framework towards a context-based approach to women's empowerment. World Development Perspectives, 20, Article 100245. https://doi.org/10.1016/j.wdp.2020.100245

Han, K.-M., Jee, H.-J., An, H., Shin, C., Yoon, H.-K., Ko, Y.-H., . . Han, C. (2019). Intimate partner violence and incidence of depression in married women: A longitudinal study of a nationally representative sample. Journal of Affective Disorders, 245, 305-311. https://doi.org/10.1016/j.jad.2018.11.041

Ivanova, T. N., \& Ustinova, M. V. (2016). Transformatsiya supruzheskikh rolei v usloviyakh globalizatsii [Transformation of marital roles in the context of globalization]. Karelian Scientific Journal, 5(3), 148-152.

Jaehn, P., Bobrova, N., Saburova, L., \& Cook, S. (2020). The relation of gender role attitudes with depression and generalised anxiety disorder in two Russian cities. Journal of Affective Disorders, 264, 348-357. https://doi.org/10.1016/j.jad.2020.01.027

Jansen, E., Harris, H., \& Rossi, T. (2020). Fathers' perceptions of their role in family mealtimes: A grounded theory study. Journal of Nutrition Education and Behavior, 52(1), 45-54. https://doi.org/10.1016/j.jneb.2019.08.012

Kabakova, M., \& Maulsharif, M. (2013). Transformation of social roles and marital relations in modern Kazakhstan: Socialpsychological analysis. Procedia-Social and Behavioral Sciences, 82, 638-641.

https://doi.org/10.1016/j.sbspro.2013.06.322

Khammatova, R. S. (2012). Sotsial'no-psikhologicheskie osobennosti semei razlichnoi etnicheskoi prinadlezhnosti [Sociopsychological features of families of different ethnic groups]. Izvestiya Samara Scientific Center of the Russian Academy of Sciences, 14(2(2)), 408-409. Retrieved from http://www.ssc.smr.ru/media/journals/izvestia/2012/2012_2_408_409.pdf

Lee, C. H., \& Kim, Y. (2018). Jongka, the traditional Korean family: Exploring jongka food in the context of Korean food categories. Journal of Ethnic Foods, 5(1), 40-53. https://doi.org/10.1016/j.jef.2018.02.006

Lee, G. N., Tsoi, A. D., Tsoi, B., Chen, V. S., \& Yugai, G. A. (2003) Entsiklopediya koreitsev Rossii [Encyclopedia of Koreans in Russia]. Moscow, Russia: RAEN. Retrieved from https://elibrary.ru/item.asp?id=19684817 
Lee, S. A., Park, E.-C., Ju, Y. J., \& Kim, T. H. (2018). The association between satisfaction with husband's participation in housework and suicidal ideation among married working women in Korea. Psychiatry Research, 261, 541-546. https://doi.org/10.1016/j.psychres.2018.01.039

Lieber, J., Clarke, L., Timæus, I. M., Carson Mallinson, P. A., \& Kinra, S. (2020). Changing family structures and self-rated health of India's older population (1995-96 to 2014). SSM—Population Health, 11, Article 100572. https://doi.org/10.1016/j.ssmph.2020.100572

Maslennikova, S. A., \& Nepryakhina, A. I. (2019). Izuchenie predstavlenii sovremennoi molodezhi v brachno-semeinykh otnosheniyakh [Studying the ideas of modern youth in marriage and family relations]. Human Capital, 5(125), 177-184. Retrieved from https://humancapital.su/wp-content/uploads/2019/05/201905_p177-184.pdf

Masuda, A. D., Sortheix, F. M., Beham, B., \& Naidoo, L. J. (2019). Cultural value orientations and work-family conflict: The mediating role of work and family demands. Journal of Vocational Behavior, 112, 294-310. https://doi.org/10.1016/j.jvb.2019.04.001

Oliferovich, N. I., Zinkevich-Kuzemkina, T. A., \& Velenta, T. F. (2006). Psikhologiya semeinykh krizisov [Psychology of family crises] (pp. 193-196). Saint Petersburg, Russia: Rech Publishing House.

Oyserman, D. (2011). Culture as situated cognition: Cultural mindsets, cultural fluency and meaning making. European Review of Social Psychology, 22(1), 164-214. https://doi.org/10.1080/10463283.2011.627187

Pinsof, W. M., \& Lebow, J. L. (2005). Family psychology: The art of the science. New York, NY, USA: Oxford University Press.

Romanova, A. V., \& Tsinchenko, G. M. (2019). Molodaya sem'ya sovremennye problemy [Young family modern problems]. Management Issues, 3(58), 204-214. Retrieved from http://vestnik.uapa.ru/issue/2019/03/21

Schenk, N., \& Dykstra, P. A. (2012). Continuity and change in intergenerational family relationships: An examination of shifts in relationship type over a three-year period. Advances in Life Course Research, 17(3), 121-132. https://doi.org/10.1016/j.alcr.2012.01.004

Shapar, V. B. (2006). Prakticheskaya psikhologiya. Psikhodiagnostika otnoshenii mezhdu roditelyami i det'mi [Practical psychology. Psychodiagnostics of relations between parents and children] (pp. 66-77). Rostov-on-Don, Russia: Phoenix Publishing House.

Singh, R., \& Nayak, J. K. (2016). Parent-adolescent conflict and choice of conflict resolution strategy: Familial holiday planning. International Journal of Conflict Management, 27(1), 88-115. https://doi.org/10.1108/IJCMA-04-2014-0025

Spivatchuk, Z. V. (2017). Osobennosti psevdopatriarkhal'nykh otnoshenii muzhchin i zhenshchin [Features of pseudoPatriarchal relations between men and women]. National Health, 1-2, 204-215. Retrieved from https://elibrary.ru/item.asp?id=30031904

Triandis, H. C. (2004). Cultural syndromes. In C. Spielberger (Ed.), Encyclopedia of applied psychology (Vol. 1, pp. 555560). Cambridge, MA, USA: Academic Press.

Ushakova, V. G., \& Hugh, S. S. (2007). Sem'ya i brachno-semeinye ustanovki molodezhi v Rossiiskoi Federatsii i respublike Koreya (po materialam sravnitel'nogo sotsiologicheskogo issledovaniya) [Family and marital and family attitudes of youth in the Russian Federation and the Republic of Korea (based on comparative sociological research)]. Bulletin of 
the Saint Petersburg University. Series 6: Philosophy. Culturology. Political science. Right. International relations, 2(1), 118-128.

Vlasova, A. S. (2020). Izuchenie etnicheskikh osobennostei konfliktov u suprugov s vysokim urovnem udovletvorennosti brakom [Study of ethnic features of conflicts in spouses with a high level of marriage satisfaction]. Young Scientist, 2(292), 205-208. Retrieved from https://moluch.ru/archive/292/66282/

von Weizsäcker, E. U., \& Wijkman, A. (2018). COME ON! Capitalism, short-termism, population and destruction of the planet - A report to the club of Rome. New York. NY, USA: Springer. https://doi.org/10.1007/978-1-4939-7419-1

Yang, M. J. H., Khoo-Lattimore, C., \& Yang, E. C. L. (2020). Three generations on a holiday: Exploring the influence of NeoConfucian values on Korean Multigenerational Family vacation decision making. Tourism Management, 78, Article 104076. https://doi.org/10.1016/j.tourman.2020.104076 